\title{
First record of Reticulocaulis mucosissimus I. A. Abbott (Naccariaceae, Rhodophyta) for the western Atlantic Ocean
}

\author{
SILVIA MARIA P. B. GUIMARÃES ${ }^{1,3}$ and GILBERTO MENEZES AMADO-FILHO²
}

(received: November 6, 2008; accepted: July 23, 2009)

\begin{abstract}
First record of Reticulocaulis mucosissimus I. A. Abbott (Naccariaceae, Rhodophyta) for the western Atlantic Ocean). Espírito Santo State lies in the transition region $\left(18^{\circ}-21^{\circ} \mathrm{S}\right)$ between the tropical and subtropical marine-algal provinces and is considered the richest area of the Brazilian flora. The subtidal substratum presents extensive areas of rhodoliths associated with a diversified marine biota. A detailed exploration using Scuba diving technique has revealed many little-known and previously unreported taxa that are new to the Brazilian coast. Among the algae recently discovered, Reticulocaulis mucosissimus I. A. Abbott was found at a depth of 25 meters, thus consisting of the second member of the infrequently encountered family Naccariaceae growing in the same region. This work has revealed additional distribution records of this species not yet reported from the western Atlantic. Description of the morphological and reproductive features of the species as well as illustrations and comments are presented.
\end{abstract}

Key words - Brazil, diversity, Espírito Santo State, Naccariaceae, Reticulocaulis mucosissimus

RESUMO - (Primeira referência de Reticulocaulis mucosissimus I. A. Abbott (Naccariaceae, Rhodophyta) para o Oceano

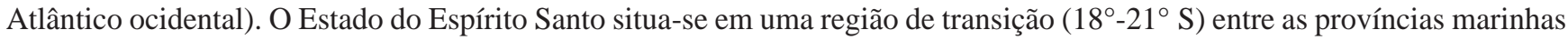
tropical e subtropical e, é considerada a área mais rica do Brasil quanto a flora marinha. A região subtidal apresenta extensas áreas de rodolitos associados com uma biota marinha diversificada. Um estudo detalhado através do emprego do mergulho autônomo Scuba está revelando muitos táxons pouco conhecidos e ainda não referidos para a costa brasileira. Entre as algas recentemente descobertas, Reticulocaulis mucosissimus I. A. Abbott foi encontrada em uma profundidade de 25 metros, constituindo-se no segundo representante da família Naccariaceae crescendo na mesma região. De um modo geral, os representantes desta família são dificilmente encontrados. Este trabalho amplia consideravelmente a distribuição desta espécie que não havia ainda sido referida para o Oceano Atlântico ocidental. A descrição das características morfológicas e reprodutivas da espécie é apresentada, assim como, ilustrações e comentários.

Palavras-chave - Brasil, diversidade, Estado do Espírito Santo, Naccariaceae, Reticulocaulis mucosissimus

\section{Introduction}

The Espírito Santo State region of Brazil (between $18^{\circ}$ and $21^{\circ}$ ) is known as a transition between tropical and subtropical marine-algal provinces being highly diverse and considered the richest region of the Brazilian marine flora (Guimarães 2006). A recent study carried out on the sublittoral marine flora of southern Espírito Santo State revealed a diverse and probably ephemeral spring-summer flora growing on rhodolith substrata (Amado-Filho et al. 2007, Guimarães \& Amado-Filho 2008). Some species identified in these habitats are red algae with a soft and mucilaginous erect habit. Naccaria corymbosa J. Agardh was the first member of the family Naccariaceae referred to Brazil and growing on rhodoliths (Guimarães \& Amado-Filho 2008). In

1. Instituto de Botânica, Av. Miguel Estefano 3687, 04301-902 São Paulo, SP, Brazil.

2. Instituto de Pesquisas Jardim Botânico do Rio de Janeiro, Rua Pacheco Leão 915, 22460-030 Rio de Janeiro, RJ, Brazil.

3. Corresponding author: smpbguimaraes@uol.com.br the present study we documented the first record of Reticulocaulis mucosissimus I. A. Abbott for the western Atlantic, being the second member of the Naccariaceae reported from Brazil.

The genus Reticulocaulis was described by Abbott (1985) for the single species $R$. mucosissimus, a strongly mucilaginous alga, with densely branched uniaxial thalli, collected during the spring at subtidal depths of 8-10 meters in Hawaii. The generic name alludes to the netlike tissue (reticulum) that encloses the axial strands. Reticulocaulis mucosissimus was recorded from Masirah Island, Oman, and a second species, $R$. obpyriformis Schils was described from the south coast of Socotra Island, Yemen, both in the Arabian Sea (Schils et al. 2003). Reticulocaulis mucosissimus was also reported from the Canary Islands (Afonso-Carrillo et al. 2006).

The present data represent new distribution records and a substantial range extension of this species. The absence of prior reports probably results from the lack of subtidal studies on the Brazilian coast. The morphological and reproductive features of the species are presented. 


\section{Material and methods}

The study area is located in the southern region of Espírito Santo, Brazil. Rhodoliths were collected in the subtidal by Scuba diving in a site on the continental shelf (21 ${ }^{\circ} 15^{\prime} 1.44^{\prime \prime} \mathrm{S}$ and $\left.40^{\circ} 35^{\prime} 27.54^{\prime \prime} \mathrm{W}\right)$ at 25 meters depth. The sea floor was covered by loose-lying rhodoliths measuring up to $10 \mathrm{~cm}$ in diameter. The collections were placed in plastic bags and latter preserved in $4 \%$ formalin-seawater. Following preliminary sorting, microscope slides were made from squash preparations stained in a solution of $1 \%$ aniline blue to which a small amount of $1 \mathrm{~N} \mathrm{HCl}$ was added. Photographs were taken using an Olympus BH-2 microscope fitted with an Olympus C35AD camera and drawings were made with the aid of a Zeiss camera lucida. Voucher specimens were deposited in the Herbarium of the Instituto de Botânica, São Paulo, Brazil (SP 355787).

\section{Results}

Reticulocaulis mucosissimus I. A. Abbott Figures 1-14

Plant reddish, erect, pyramidal, anchored by an inconspicuous basal pad, $10 \mathrm{~cm}$ in length, mucilaginous and slippery with the accumulation of detritus in the mucilage (figures 1, 2). Thallus consists of one terete

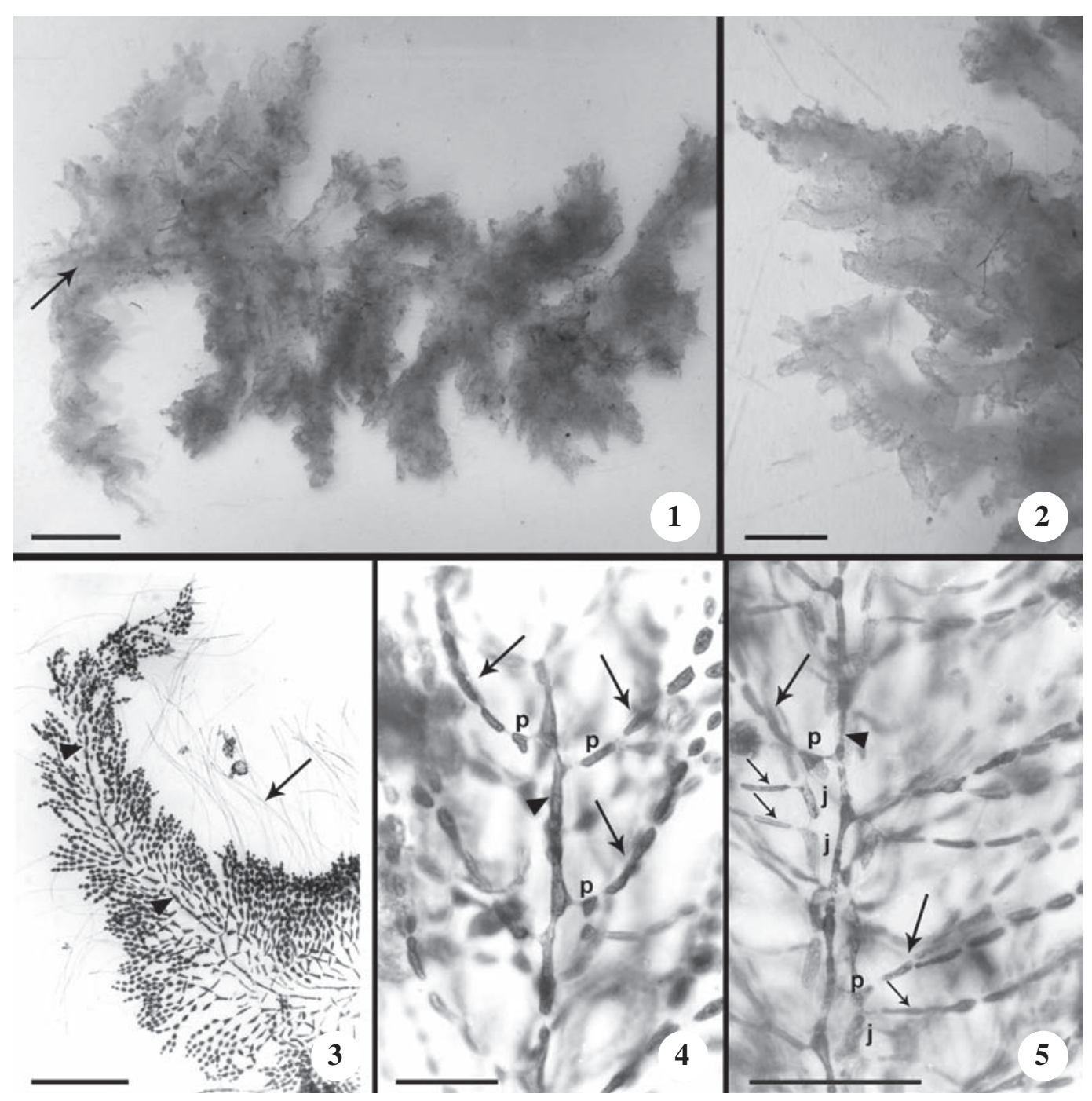

Figures 1-5. Reticulocaulis mucosissimus. 1. Habit of the liquid preserved specimen with a main axis (arrow) and branches of several orders. 2. Detail of the lateral branches. 3. Apex of an indeterminate axis (arrowheads) showing the central-axial filament and the cortical fascicles. The arrow indicates numerous hairs. 4. Detail of the central-axial filament (arrowhead) in a young part of the axis showing periaxial cells (p) and primary cortical fascicles (arrows). 5. Detail of the central-axial filament (arrowhead) in a young part of the axis showing periaxial cells (p), jacket cells (j), primary (large arrow) and secondary cortical fascicles (small arrow). Bar $=1 \mathrm{~cm}$ (1), $0.5 \mathrm{~cm}$ (2), $200 \mu \mathrm{m}$ (3), $50 \mu \mathrm{m}$ (4), $100 \mu \mathrm{m}$ (5). 


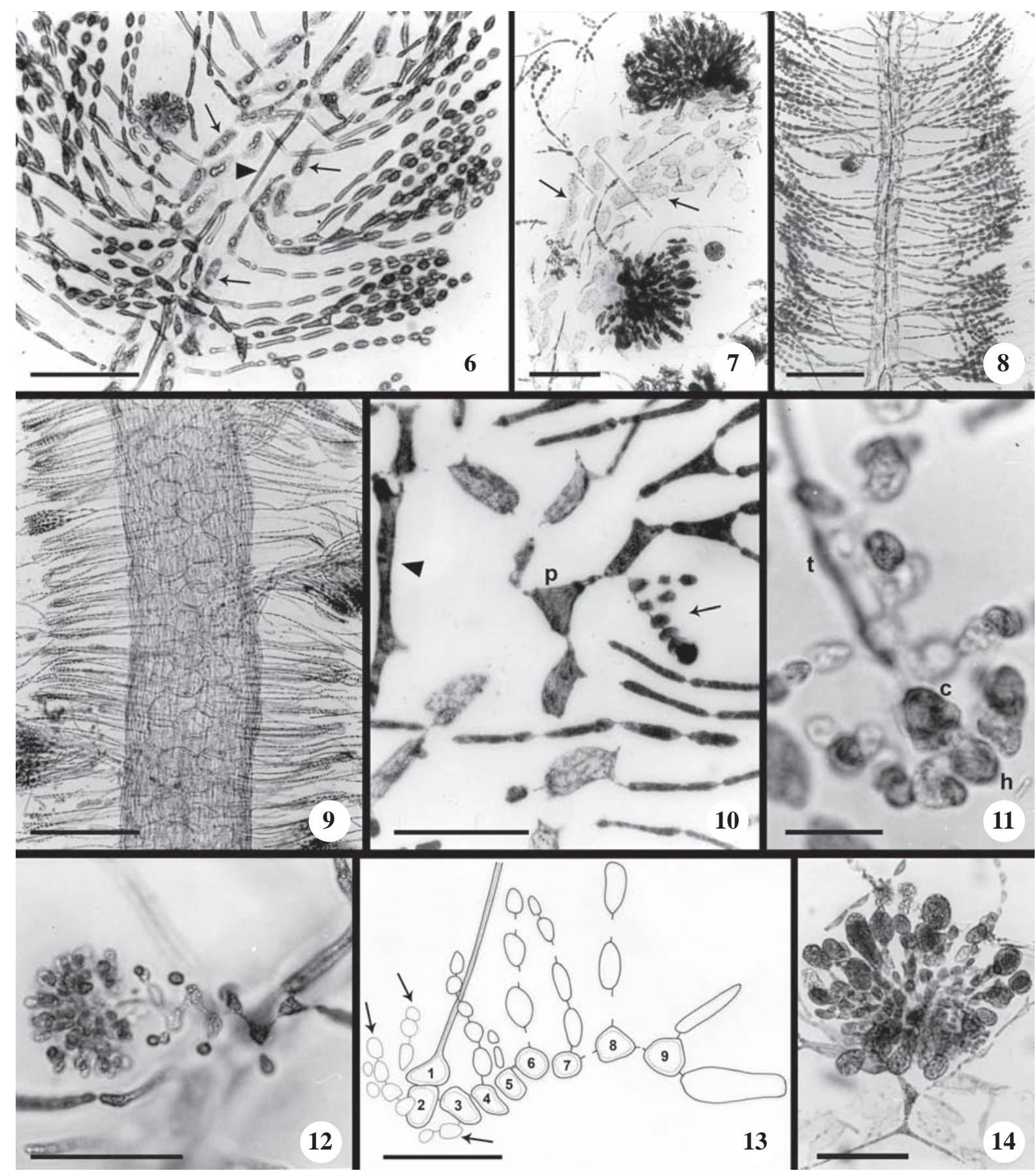

Figures 6-14. Reticulocaulis mucosissimus. 6. Central-axial filament (arrowhead) surrounded by a sheath of jacket cells (arrows) and the cortical fascicles. A young developing carposporophyte is seen. 7. Central-axial filament surrounded by a sheath of jacket cells (arrows). Two mature carposporophytes are seen. 8. Portion of a young branch showing the axial sheath and the cortical fascicles. 9. Mature branch with a wide sheath of inflated cells and cortical fascicles. 10. First stages of the development of the carpogonial branch (arrow) from a basal cell of a cortical filament. The arrowhead indicates the central-axial filament; $\mathrm{p}=$ periaxial cell. 11. Young carpogonial branch with the carpogonium (c) and the hypogynous cell (h). The trichogyne (t) is in a lower plane. 12. Cells of the carpogonial branch with a zigzag arrangement and densely clustered nutritive cells. 13. Detail of a carpogonial branch composed of nine cells designated by numbers (1-9), starting with the terminal carpogonium (1). The carpogonium has produced a trichogyne and sterile laterals have arisen perpendicularly and adaxially from most of the cells of the carpogonial branch. Nutritive-cell clusters on the hypogynous cell (2) and on cell 3 (arrows). The basal cell (9) of the carpogonial branch is attached to a cell of a cortical filament. 14. Detail of the mature carposporophyte with terminal carposporangia. $\mathrm{Bar}=100 \mu \mathrm{m}$ (6, 14), $200 \mu \mathrm{m}$ (7, 8), $500 \mu \mathrm{m}$ (9), $50 \mu \mathrm{m}$ (10, 12), $15 \mu \mathrm{m}$ (11), $30 \mu \mathrm{m}(13)$. 
main axis up to $2 \mathrm{~mm}$ in diameter, with many densely radially indeterminate branches arranged around the main axis. Each branch redivided to 3-4 orders and is densely covered by determinate branches that constitute the cortex. Young branches tapering to relatively acute apices (figure 3).

Structure uniaxial, the central-axial filament distinct (figure 3). Apical cell not evident. Central-axial cells slender and elongate, those lying $c a .200 \mu \mathrm{m}$ from the apex being $20 \mu \mathrm{m}$ in length and $6.5 \mu \mathrm{m}$ in diameter. Each axial cell cuts off two initials (periaxial cells) of determinate cortical fascicles (figure 4) at opposite ends of the axial cell. The superior periaxial (distal periaxial) cell becomes elongated and subcylindrical, and will be retained in its subterminal position. The inferior periaxial (proximal periaxial) cell remains approximately isodiametric and will be displaced to a middle position, as a consequence of the elongation of the central-axial cell. Derivatives of the periaxial cells differentiate by branching into determinate filaments that constitute the primary cortical fascicles (figure 4). Cortical fascicles pseudodichotomous with some surface cells near the apices with vegetative hairs (figure 3 ). Cortical filaments 150-500 $\mu \mathrm{m}$ in length and 7-14 cell layers in thickness. The inner cortical cells are cylindrical, whereas the outer cells remain ovoid to subspherical and 6-7.8 $\mu \mathrm{m}$ in diameter.

Periaxial cells initiate several downward-growing filaments running parallel to the central axis (figure 5). The cells of these filaments soon establish pit-connections and later come to form the distinctive netlike jacket of cells (figures 6, 7). A secondary cortical filament arises from each jacket cell. The netlike tissue interconnected by secondary pit connections constituted a sheath around the axial strand (figure 8). In the mature parts of the thallus, we observed a central axial strand completely surrounded by a jacket of inflated and colourless cells, from which emerge the determinate branches (figure 9). In older parts of the thallus rhizoidal filaments consisting of slender cells densely cover the inflated cells.

Spermatangia not observed. Carpogonial branches are scattered throughout the thallus in various stages of development (figures 10, 11). Cells of the carpogonial branch with zigzag arrangement (figure 12). The carpogonial branch is seven to nine cells long, the basal cell being a periaxial or one of the lower cortical cells (figure 13). These cells are designated by numbers starting with the carpogonium (number 1). The carpogonium is conical, 5-7.5 $\mu \mathrm{m}$ in width projecting into a long trichogyne. The hypogynous cell produces branched clusters of nutritive cells. Cells numbers 3 and 4 can also present nutritive-cell clusters (figure 13). The lower cells $(4,5,6,7,8,9)$ of the carpogonial branches present sterile laterals up to 12 cells in length that arise perpendicularly and adaxially. In mature carpogonial branches the carpogonium is surrounded by a mass of nutritive cells (figure 12). After fertilization the carpogonial branch cells and the basal cells of the sterile laterals inflate and the pit connections enlarge. Initiation of the gonimoblast from the carpogonium not observed. Derivatives of the gonimoblast initial form branched filaments bearing terminal carpospores (figure 14). Mature carposporophyte $250-350 \mu \mathrm{m}$ in diameter and without involucral filaments. Cystocarps at various stages of development are found scattered within the cortex. Tetrasporophytes unknown.

Material examined: BRAZIL. EsPíRITO SANTo State: 21'15'1.44” S and 40 35'27.54” W, 25 meters depth, 5-XII-2007, G.M. Amado-Filho s.n.(SP 355787).

Habitat: growing on rhodolith. A single female gametophyte was collected.

Distribution: Pacific Ocean: Hawaii. Indian Ocean, Arabian Sea: Masirah Island, Oman. Atlantic Ocean: Canary Islands and Brazil.

Type locality: Oahu Island, Hawaii.

\section{Discussion}

Representatives of the Naccariaceae (species of Naccaria Endlicher, Atractophora P. Crouan et H. Crouan and Reticulocaulis I. A. Abbott) show ephemeral seasonal gametophytes with infrequent occurrence (Millar 1990, Womersley 1996, Afonso-Carrillo et al. 2006). Naccaria has five species occurring in Europe, the Caribbean, Hawaii and Australia. Atractophora is monotypic from Europe, and Reticulocaulis has two species occurring in Hawaii, Canary Is. and Arabian Sea (Abbott 1985, Schils et al. 2003, Afonso-Carrillo et al. 2006). Huisman et al. (2000) described from the Caribbean Sea a monotypic genus Liagorothamnion Huisman, D.L. Ballant. \& M.J. Wynne included in its own tribe (Liagorothamnieae) within the Ceramiaceae and its species Liagorothamnion mucoides Huisman, D.L. Ballant. \& M.J. Wynne. Schils et al. (2003), analysing the post-fertilization process in Liagorothamnion found that it was very similar to that reported for Atractophora (Millar 1990) and that additionally these two genera have a number of striking similarities. Schils et al. (2003) presented evidence to assign Liagorothamnion to the Naccariaceae rather than to the Ceramiaceae. Schneider \& Wynne (2007) also included Liagorothamnion into Naccariaceae. 
The term "jacket cells" was employed by Abbott (1985) to refer to the cells that mutually cross-connect by lateral secondary pit connections and constitute a sheath around the central-axial strand.

We have found only one specimen that probably represents an ephemeral spring-summer element of the wider macroalgal flora. The habit of the Brazilian plant is very similar to the material from Hawaii and Oman, differing a little from the Canarian specimen that seems to be more densely branched. Schils et al. (2003) presented the mainly morphological features that distinguish Reticulocaulis mucosissimus from $R$. obpyriformis. Reticulocaulis mucosissimus presents slender axial cells, gradual acropetal transition of cortical cells from cylindrical to spherical and dioecious thalli.

In our specimen post-fertilization events could not be followed clearly because of the numerous and densely packed cells that are at the bases of developing carposporophytes. According to Abbott (1985) it seems that the gonimoblast is initiated from the carpogonium, not from the hypogynous cell. Schils et al. (2003) reported that the gonimoblast initial develops directly from the fertilized carpogonium. Our observations agree with Schils et al. (2003) that the carposporangia are terminal on branched gonimoblast filaments.

Tetrasporangial thalli are unknown to the genus. According to Schils et al. (2003), based on what is known for other genera of Naccariaceae, it is presumed that Reticulocaulis has a heteromorphic life history involving a minute system of prostrate filaments bearing terminal tetrahedral tetrasporangia.

The present data represent new distribution records and a substantial range extension, although the species may in fact prove to have much wider Brazilian and western tropical-Atlantic distributions. The absence of prior reports is probably a result of their brief seasonal appearance and general lack of subtidal studies in these areas.

Acknowledgements - This work was partially supported by the Brazilian Research Council - CNPq - by grants to S.M.P.B. Guimarães and G.M. Amado-Filho.

\section{References}

ABBOTT, I.A. 1985. Vegetative and reproductive morphology in Reticulocaulis gen. nov. and Naccaria hawaiiana sp. nov. (Rhodophyta, Naccariaceae). Journal of Phycology 21:554-561.

AFONSO-CARRILLO, J., SANSÓN, M. \& SANGIL, C. 2006. First report of Reticulocaulis mucosissimus (Naccariaceae, Rhodophyta) for the Atlantic Ocean. Cryptogamie, Algologie 27:255-264.

AMADO-FILHO, G.M., MANEVELDT, G., MANSO, R.C.C., MARINS-ROSA, B.V., PACHECO, M.R. \& GUIMARÃES, S.M.P.B. 2007. Structure of rhodolith beds from 4 to 55 meters deep along the southern coast of Espírito Santo State, Brazil. Ciencias Marinas 32:399410.

GUIMARÃES, S.M.P.B. 2006. A revised checklist of benthic marine Rhodophyta from the State of Espírito Santo, Brazil. Boletim do Instituto de Botânica, São Paulo 17:143-194.

GUIMARÃES, S.M.P.B. \& AMADO-FILHO, G.M. 2008. A community of gelatinous rhodophytes in the sublittoral of southern Espírito Santo State, Brazil. Botanica Marina 51:378-387.

HUISMAN, J.M., BALLANTINE, D.L. \& WYNNE, M.J. 2000. Liagorothamnion mucoides gen. et sp. nov. (Ceramiaceae, Rhodophyta) from the Caribbean Sea. Phycologia 39:507-516.

MILLAR, A.J.K. 1990. Marine red algae of the Coffs Harbour region, northern New South Wales. Australian Systematic Botany 3:293-593.

SCHILS, T., DE CLERCK, O. \& COPPEJANS, E. 2003. The red algal genus Reticulocaulis from the Arabian Sea, including $R$. obpyriformis sp. nov., with comments on the family Naccariaceae. Journal of Phycology 42:4455.

SCHNEIDER, C.W. \& WYNNE, M.J. 2007. A synoptic review of the classification of the red algal genera a half century after Kylin's "Die Gattungen der Rhodophyceen”. Botanica Marina 50:197-249.

WOMERSLEY, H.B.S. 1996. The marine benthic flora of southern Australia - Part III B - Gracilariales, Rhodymeniales, Corallinales and Bonnemaisoniales. Australian Biological Resources Study, Canberra. 